\title{
Plot size and number of replications to assess the vegetable matter in oat
}

\author{
André Lavezo, Alberto Cargnelutti Filho*, Bruna Mendonça Alves, \\ Denison Esequiel Schabarum, Daniela Lixinski Silveira, Gabriela Görgen Chaves
}

Federal University of Santa Maria, Brazil

${ }^{*}$ Corresponding author, e-mail: alberto.cargnelutti.filho

\begin{abstract}
The determination of the optimum plot size in agricultural crops is important for obtaining accurate inferences in the treatments in question. This study aimed at determining the optimum plot size (Xo) and the number of replications to evaluate the fresh matter (FM) and the dry matter (DM) of oat and at verifying the variability of Xo among cultivars and sowing dates. Ninety-six uniformity trials of $3 \times 3 \mathrm{~m}$ were performed and each assay was divided into 36 basic experimental units (BEU) of $0.5 \times 0.5 \mathrm{~m}$. The 96 uniformity trials were distributed in four cultivars and three sowing dates. At the flowering stage, FM and DM were determined in each BEU. Then, the Xo was determined in each uniformity assay, using the maximum curvature method of the coefficient of variation model. In oat, there is variability of Xo among cultivars and sowing dates to measure FM and DM. For the four cultivars on the three sowing dates, the Xo of $1.66 \mathrm{~m} 2$ and of $1.73 \mathrm{~m} 2$ are suitable to evaluate FM and DM, respectively. Four replications to evaluate the maximum of 50 treatments in completely randomized design and randomized blocks design are sufficient so that the differences among treatment means of $44.75 \%$ of the experiment mean may be significant, using the Tukey test at $5 \%$ probability to measure FM and DM in oat.
\end{abstract}

Keywords: Avena sativa L., experimental design, uniformity trials

\section{Introduction}

The oat (Avena sativa L.) is the main winter grass sown in southern Brazil and it is the fifth most cultivated cereal (IBGE, 2014). It is an economically viable alternative for cultivation in the winter/spring period, occupying part of the agricultural areas that would lie fallow this time of the year. It is an annual herbaceous plant with great potential to be used as food for both humans and animals. The oat can also be used in the crop rotation system due to its soil restoration properties, having an aggressive root system and a large amount of matter. Furthermore, this plant influences the development of the soil biota, as observed in the study by Cardoso et al. (2014),

thus improving the microbiological soil conditions.

Due to the relevance of the oat cultivation, several studies have been conducted (Floss et al., 2007; Grecco et al., 2011 ; Demétrio et al., 2012; Meinerz et al., 2012; Tafernaberri Júnior et al., 2012; Ferrazza et al., 2013; Soares et al., 2013; labal et al., 2014; Khan et al., 2014) in order to improve knowledge and to investigate the productivity of fresh and dry matter. Nevertheless, researchers have been using different plot sizes in these experiments, ranging from $0.25 \mathrm{~m} 2$ (Soares et al., 2013) to $10.8 \mathrm{~m}^{2}$ (labal et al., 2014).

The fresh matter on plants is an important property to be assessed, for it reveals the potential and the performance of plants and their benefits 
for the soil and for the succeeding crops. According to Cardoso et al. (2014), in a study of soil covering plants, which includes oat, they provided a $10 \%$ increase in soybean productivity. Likewise, the dry matter, which is a percentage related to the fresh matter, has the same benefits.

The determination of the optimum plot size and of the number of replications from data collected in uniform trials (trials without treatments) allows the researcher to obtain a precise inference in the experiments, serving as a base to carrying out future research with cultivation. Thus, theoretically, based on the literature, the researcher can be guided on which plot size and number of replications one should use.

The optimum plot size can be determined by the maximum curvature method of the coefficient of variation model proposed by Paranaíba et al. (2009). It is assumed that the optimum plot size and the number of replications differ among cultivars and sowing dates of oat. Therefore, this study aimed at determining the optimum plot size and the number of replications to evaluate the fresh matter and the dry matter of oat and at verifying the variability of the optimal plot size among cultivars and sowing dates.

\section{Material and Methods}

Field experiments

Ninety-six uniformity trials were conducted with the oat crop (Avena sativa L.) in an experimental area of $90 \times 60 \mathrm{~m}(5,400$ $\mathrm{m}^{2}$ ), from the Department of Phytotechny of the Santa Maria Federal University, Santa Maria, State of Rio Grande do Sul, located at $29^{\circ} 42^{\prime} S$, $53^{\circ} 49^{\prime} \mathrm{W}$ and $95 \mathrm{~m}$ high, in the agricultural year of 2014. The sowing density was 350 plants $\mathrm{m}^{-2}$, with throwing sowing. The base fertilization was $21 \mathrm{~kg}$ $\mathrm{ha}^{-1} \mathrm{~N}, 88 \mathrm{~kg} \mathrm{P} 2 \mathrm{O} 5 \mathrm{ha}^{-1}$ and $88 \mathrm{~kg} \mathrm{ha}^{-1}$ of $\mathrm{K} 2 \mathrm{O}$ and later two $45 \mathrm{~kg} \mathrm{ha}^{-1} \mathrm{~N}$ covering fertilizations were performed. The cultivation tracts were carried out homogeneously throughout the experimental area.

The 96 uniformity trials were conducted as follows: eight uniformity trials with the URS Charrua cultivar, eight with the URS Taura cultivar, eight with the URS Estampa cultivar and eight with the URS Corona cultivar in each of the three sowing dates (date 1 - 04/28/2014, date 2 - 05/28/2014 and date 3 -07/14/2014). Each uniformity assay of size $3 \times 3 \mathrm{~m}\left(9 \mathrm{~m}^{2}\right)$ was divided in 36 basic experimental units (BEU) of $0.5 \times 0.5$ $\mathrm{m}\left(0.25 \mathrm{~m}^{2}\right)$, forming a matrix of six lines and six columns.

\section{Measurement of variables}

At the flowering stage, at each BEU of $0.25 \mathrm{~m}^{2}$, the plants were cut off at the surface of the soil. After that, they were weighed to obtain the fresh matter (FM) in $\mathrm{kg}$ per $0.25 \mathrm{~m}^{2}$. Subsequently, five plants from each BEU were randomly collected. The FM of these five plants was weighed and placed into an air forced circulation greenhouse at $338.15 \pm 276.15 \mathrm{~K}$ until constant matter was attained. Then, the dry matter (DM) was weighed and converted in $\mathrm{kg}$ per $0.25 \mathrm{~m}^{2}$

Estimation of optimum plot size and comparison of means

For each uniformity assay, with the data of FM and DM of $36 \mathrm{BEU}$, the first-order spatial autocorrelation coefficient ( $\rho)$, the variance (s2), the mean $(\mathrm{m})$ and the coefficient of variation of the assay (CV) were determined in percentage. The estimate of $\rho$ was obtained in the direction of the columns, according to the methodology of Paranaíba et al. (2009). To this end, a path was followed from the BEU located in line 1, column 1 to line 6 , column 1, returning from line 6 , column 2 to line 1 , column 2 , and so on until the completion of the path on the BEU line 1, column 6.

Subsequently, in each of the 96 trials, the optimum plot size (Xo) was determined by the maximum curvature method of the coefficient of variation model using the expression of the Paranaíba et al. (2009)

$$
x_{O}=\left(10 \sqrt[3]{2\left(1-\rho^{2}\right) s^{2} m}\right) / m
$$

Next, the coefficient of variation of the optimum plot size ( $C V X o)$ was determined in percentage by the expression

$$
C V_{x_{0}}=\left(\sqrt{\left(1-\rho^{2}\right) s^{2} / m^{2}}\right) / \sqrt{x_{0}} \times 100
$$

Thus, for each cultivar on each sowing date, eight $\rho$ estimates, $s 2, m, C V, X_{0}$ and $C V X_{0}$ 
were obtained. The comparison of the statistics means of $\rho, s 2, m, C V, X_{0}$ and $C V X_{O}$ among cultivars (URS Charrua, URS Taura, URS Estampa and URS Corona) and among sowing dates (date 1 - 04/28/2014, date $2-05 / 28 / 2014$ and date 3 $07 / 14 / 2014$ ), with $n=8$ uniformity trials per cultivar on each sowing date, was carried out using the Scott Knott test via bootstrap analysis with 10,000 resampling with a $5 \%$ probability.

\section{Estimation of number of replications}

The minimum significant difference (d) of the Tukey test, expressed in percentage of the experiment mean was estimated by the expression

$$
d=\left(q_{a(i ; G L E)} \sqrt{Q M E / r}\right) / m \times 100
$$

in which qa (i;GLE) is the critical value of the Tukey test at the a level of error probability $(a=0.05$ in this study), $i$ is the number of treatments, GLE is the number of degrees of freedom for error, i.e., i ( $r-1)$ for a completely randomized design and $(i-1)(r-1)$ for a randomized blocks design, QME is the squared mean of the error, $r$ is the number of replications and $m$ is the experiment mean. Substituting the expression of the experimental coefficient of variation

$$
(C V=\sqrt{Q M E} / m \times 100)
$$

in percentage, in the expression to calculate $d$ and isolate r resulting in

$$
r=\left(q_{a(i ; G L E)} C V / d\right)^{2}
$$

The experimental coefficient of variation of the expression corresponds to CVXo and it is expressed in percentage, for it is the expected CV to the experiment with the determined optimum plot size (Xo). From the highest means of CVXo of the cultivars and of the three dates of evaluation, the number of replications ( $r$ ) was determined by iterative process until convergence, for experiments in completely randomized design and randomized blocks design, in scenarios formed by combinations of $i(i=3,4, \ldots, 50)$ and $d(d=10 \%, 15 \%, 20 \%, 25 \%, 30 \%, 35 \%, 40 \%, 45 \%$ and $50 \%)$.
Resources used for the calculations

Statistical analyzes were performed using the Microsoft Office Excel® application and the Sisvar® software (Ferreira, 2014).

\section{Results}

Descriptive statistics

Variability was found on the following statistics: first-order spatial autocorrelation coefficient ( $\rho)$, variance (s2), mean (m) and coefficient of variation of the assay (CV). Accordingly, there was variability of the estimates of the optimum plot size (Xo) and of the coefficient of variation of the optimum plot size ( $C V X O)$, because by using the maximum curvature method of the coefficient of variation model (Paranaíba et al., 2009), the Xo and the CVXo are calculated based on $\mathrm{p}, \mathrm{s} 2$ and $\mathrm{m}$.

\section{Analysis of variance}

Based on the Scott Knott test via bootstrap analysis, it was observed that the firstorder spatial autocorrelation coefficient $(\rho)$ did not differ among cultivars for the properties of fresh and dry matter, with the exception of the property of dry matter at the date 3 . Among the sowing dates, differences were observed in the $\rho$ with the data of the properties of fresh matter from the URS Taura cultivar and dry matter from the URS Charrua and URS Taura cultivars (Table 1).

Concerning the data of the fresh and dry matter of oat, differences among cultivars and among sowing dates were found on the variance $(\mathrm{s} 2)$, mean $(\mathrm{m})$, coefficient of variation (CV) and, consequently, on the optimum plot size ( $\mathrm{XO}$ ) and coefficient of variation of the optimum plot size (CVXo) (Table 1).

\section{Average fresh matter}

The mean of fresh matter among cultivars of oat from the URS Charrua cultivar, with 0.80431 $\mathrm{kg} 0.25 \mathrm{~m}^{-2}, 0.87205 \mathrm{~kg} 0.25 \mathrm{~m}^{-2}$ and $0.83615 \mathrm{~kg}$ $0.25 \mathrm{~m}^{-2}$ for the dates 1,2 and 3 , respectively, was higher than the URS Taura, URS Estampa and URS Corona cultivars (Table 1). Regarding the sowing dates, the mean of the fresh matter of oat in the URS Charrua and URS Taura cultivars was higher on the date 2 , with $0.87205 \mathrm{~kg} 0.25 \mathrm{~m}^{-2}$ and $0.686 .75 \mathrm{~kg} 0.25 \mathrm{~m}^{-2}$, respectively, differing 
from the other dates. In the URS Estampa and URS in the production of fresh matter (Table 1). Corona cultivars, the sowing dates did not differ

Table 1. First-order spatial autocorrelation coefficient $(\rho)$, variance $\left(s^{2}\right)$, mean $(m)$, coefficient of variation of the assay (CV, in \%), optimum plot size (Xo, in number of BEU of $0.25 \mathrm{~m}^{2}$ ) and coefficient of variation of the optimum plot size $\left(\mathrm{CV}_{\mathrm{xo}_{0}}\right.$ in \%), to the aerial part of fresh matter $\left(\mathrm{kg} 0.25 \mathrm{~m}^{-2}\right)$ and the aerial part of dry matter $\left(\mathrm{kg} 0.25 \mathrm{~m}^{-2}\right)$ of four cultivars of oat (URS Charrua, URS Taura, URS Estampa and URS Corona) sown on three dates(1)

\begin{tabular}{|c|c|c|c|c|c|c|c|c|}
\hline \multirow[t]{2}{*}{ Date } & \multicolumn{4}{|c|}{ Fresh matter } & \multicolumn{4}{|c|}{ Dry matter } \\
\hline & URS Charrua & URS Taura & URS Estampa & URS Corona & URS Charrua & URS Taura & URS Estampa & URS Corona \\
\hline & \multicolumn{8}{|c|}{ First-order spatial autocorrelation coefficient $(\rho)$} \\
\hline (04/28/2014) & $0.13 \mathrm{Aa}$ & $0.34 \mathrm{Aa}$ & $0.28 \mathrm{Aa}$ & $0.13 \mathrm{Aa}$ & $0.07 \mathrm{Aa}$ & $0.30 \mathrm{Aa}$ & $0.28 \mathrm{Aa}$ & $0.16 \mathrm{Aa}$ \\
\hline (05/28/2014) & $0.11 \mathrm{Aa}$ & $0.24 \mathrm{Aa}$ & $0.13 \mathrm{Aa}$ & $0.18 \mathrm{Aa}$ & $0.16 \mathrm{Aa}$ & $0.20 \mathrm{Aa}$ & $0.14 \mathrm{Aa}$ & $0.13 \mathrm{Aa}$ \\
\hline \multirow[t]{2}{*}{ (07/14/2014) } & $-0.03 \mathrm{Aa}$ & $0.10 \mathrm{Ba}$ & $0.10 \mathrm{Aa}$ & $0.17 \mathrm{Aa}$ & $-0.10 \mathrm{Bb}$ & $0.04 \mathrm{Ba}$ & $0.15 \mathrm{Aa}$ & $0.04 \mathrm{Aa}$ \\
\hline & \multicolumn{8}{|c|}{ variance $\left(s^{2}\right)$} \\
\hline (04/28/2014) & 0.02788 Bb & $0.04197 \mathrm{Aa}$ & $0.02671 \mathrm{Ab}$ & $0.02676 \mathrm{Bb}$ & $0.00124 \mathrm{Cb}$ & $0.00186 \mathrm{Aa}$ & $0.00131 \mathrm{Bb}$ & $0.00098 \mathrm{Bb}$ \\
\hline (05/28/2014) & $0.04731 \mathrm{Aa}$ & $0.05559 \mathrm{Aa}$ & $0.03781 \mathrm{Aa}$ & $0.05004 \mathrm{Aa}$ & $0.00175 \mathrm{Ba}$ & $0.00187 \mathrm{Aa}$ & $0.00129 \mathrm{Bb}$ & $0.00199 \mathrm{Aa}$ \\
\hline (07/14/2014) & $0.03815 \mathrm{Aa}$ & $0.02413 \mathrm{Ba}$ & \multicolumn{4}{|c|}{ average $(\mathrm{m})$} & $0.00232 \mathrm{Aa}$ & $0.00270 \mathrm{Aa}$ \\
\hline (04/28/2014) & $0.80431 \mathrm{Ba}$ & $0.49591 \mathrm{Bd}$ & $0.64266 \mathrm{AC}$ & $0.72662 \mathrm{Ab}$ & $0.15367 \mathrm{Ba}$ & $0.09787 \mathrm{AC}$ & $0.12916 \mathrm{Ab}$ & $0.13303 \mathrm{Bb}$ \\
\hline (05/28/2014) & $0.87205 \mathrm{Aa}$ & $0.68675 \mathrm{Ab}$ & $0.68845 \mathrm{Ab}$ & $0.64852 \mathrm{Ab}$ & $0.15532 \mathrm{Ba}$ & $0.11732 \mathrm{Ab}$ & $0.11552 \mathrm{Bb}$ & $0.12389 \mathrm{Bb}$ \\
\hline$(07 / 14 / 2014)$ & $0.83615 \mathrm{Ba}$ & $0.51149 \mathrm{BC}$ & $\begin{array}{l}0.63320 \mathrm{Ab} \\
\text { coefficie }\end{array}$ & $\begin{array}{l}0.68204 \mathrm{Ab} \\
\text { ient of variatic }\end{array}$ & $\begin{array}{l}0.17944 \mathrm{Aa} \\
\text { on of the trial (C }\end{array}$ & $\begin{array}{l}0.11830 \mathrm{AC} \\
\mathrm{CV}, \text { in \%) }\end{array}$ & $0.13881 \mathrm{AC}$ & $0.16256 \mathrm{Ab}$ \\
\hline$(04 / 28 / 2014)$ & $20.78 \mathrm{Bb}$ & $41.51 \mathrm{Aa}$ & $25.85 \mathrm{Ab}$ & $22.47 \mathrm{Cb}$ & $22.90 \mathrm{Bb}$ & $44.13 \mathrm{Aa}$ & $28.34 \mathrm{Ab}$ & $23.54 \mathrm{Bb}$ \\
\hline (05/28/2014) & $24.87 \mathrm{Ab}$ & $34.55 \mathrm{Ba}$ & $28.17 \mathrm{Ab}$ & $35.75 \mathrm{Aa}$ & 26.77 AC & $36.50 \mathrm{Aa}$ & $31.01 \mathrm{Ab}$ & $37.57 \mathrm{Aa}$ \\
\hline$(07 / 14 / 2014)$ & $23.20 \mathrm{Ac}$ & $31.07 \mathrm{Ba}$ & $30.28 \mathrm{Aa}$ & $26.65 \mathrm{Bb}$ & $27.76 \mathrm{Aa}$ & $34.71 \mathrm{Aa}$ & $34.28 \mathrm{Aa}$ & $31.59 \mathrm{Aa}$ \\
\hline \multicolumn{9}{|c|}{ optimal plot size (Xo, in the number of BEU of $0,25 \mathrm{~m}^{2}$ ) } \\
\hline$(04 / 28 / 2014)$ & $4.27 \mathrm{Bb}$ & $6.62 \mathrm{Aa}$ & $4.86 \mathrm{Ab}$ & $4.59 \mathrm{Cb}$ & $4.64 \mathrm{Bb}$ & $6.93 \mathrm{Aa}$ & $5.17 \mathrm{Bb}$ & $4.70 \mathrm{Bb}$ \\
\hline$(05 / 28 / 2014)$ & $4.94 \mathrm{Ab}$ & $6.00 \mathrm{Aa}$ & $5.32 \mathrm{Ab}$ & $6.17 \mathrm{Aa}$ & $5.17 \mathrm{AC}$ & $6.28 \mathrm{Aa}$ & $5.65 \mathrm{Ab}$ & $6.42 \mathrm{Aa}$ \\
\hline$(07 / 14 / 2014)$ & 4.71 Ab & $5.66 \mathrm{Aa}$ & $5.55 \mathrm{Aa}$ & $5.10 \mathrm{Bb}$ & $5.30 \mathrm{Aa}$ & $6.11 \mathrm{Aa}$ & $6.07 \mathrm{Aa}$ & $5.78 \mathrm{Aa}$ \\
\hline \multicolumn{9}{|c|}{ coefficient of variation of optimal plot size $\left(\mathrm{CV}_{\mathrm{xo}^{\prime}}\right.$ in \%) } \\
\hline$(04 / 28 / 2014)$ & $9.55 \mathrm{Bb}$ & $14.80 \mathrm{Aa}$ & $10.86 \mathrm{Ab}$ & $10.26 \mathrm{Cb}$ & $10.37 \mathrm{Bb}$ & $15.50 \mathrm{Aa}$ & $11.57 \mathrm{Bb}$ & $10.52 \mathrm{Bb}$ \\
\hline (05/28/2014) & $11.05 \mathrm{Ab}$ & $13.41 \mathrm{Aa}$ & $11.90 \mathrm{Ab}$ & 13.79 Aa & $11.56 \mathrm{AC}$ & $14.03 \mathrm{Aa}$ & $12.64 \mathrm{Ab}$ & $14.36 \mathrm{Aa}$ \\
\hline$(07 / 14 / 2014)$ & $10.52 \mathrm{Ab}$ & $12.67 \mathrm{Aa}$ & $12.41 \mathrm{Aa}$ & $11.41 \mathrm{Bb}$ & $11.86 \mathrm{Aa}$ & $13.67 \mathrm{Aa}$ & $13.58 \mathrm{Aa}$ & $12.92 \mathrm{Aa}$ \\
\hline
\end{tabular}

Average dry matter

The means of the dry matter of oat among cultivars that were sown at three sowing dates differed among themselves (Table 1). On the three sowing dates (date 1, date 2 and date $3)$, the dry matter of oat was higher in the URS Charrua cultivar, with $0.15367 \mathrm{~kg} 0.25 \mathrm{~m}^{-2}, 0.15532$ $\mathrm{kg} 0.25 \mathrm{~m}^{-2}$ and $0.17944 \mathrm{~kg} 0.25 \mathrm{~m}^{-2}$, respectively, differing from the URS Taura, URS Estampa and URS Corona cultivars. In reference to sowing dates, the mean of the dry matter of oat in the URS Charrua and URS Corona cultivars was higher on the date 3, with $0.17944 \mathrm{~kg} 0.25 \mathrm{~m}^{-2}$ and 0.16256 $\mathrm{kg} 0.25 \mathrm{~m}-2$, respectively, differing from dates 1 and 2; concerning the URS Taura cultivar, the sowing dates did not differ in relation to the dry matter; in the URS Estampa cultivar, the highest mean was obtained on the date $1(0.12916 \mathrm{~kg}$ $\left.0.25 \mathrm{~m}^{-2}\right)$ and the date $3\left(0.13881 \mathrm{~kg} 0.25 \mathrm{~m}^{-2}\right)$ and did not differ among themselves, nevertheless, they differed from the date $2\left(0.11552 \mathrm{~kg} 0.25 \mathrm{~m}^{-2}\right)$ (Table 1).

\section{Coefficient of variation}

The means of the coefficient of variation (CV) oscillated between $20.78 \%$ and $22.90 \%$ for the URS Charrua cultivar on the date 1 and $41.51 \%$ and $44.13 \%$ for the URS Taura cultivar on the date 1 (Table 1) for the data of fresh and dry matter of oat, respectively.

Optimum plot size and coefficient of variation of optimum plot size

Regarding the means of the optimum plot size (XO) and of the coefficient of variation of the optimum plot size ( $\mathrm{CV} \times \mathrm{O})$, for measuring the fresh matter of oat, significant differences among cultivars were observed, resulting in the obtainment of a larger optimum plot size and a higher coefficient of variation of the optimum 
plot size in the URS Taura cultivar ( $\mathrm{XO}_{\mathrm{O}}=6.62$ and CVXo $=14.80 \%)$ on the date 1 , in the URS Taura ( $X_{O}=6.0$ and $C V x O=13.41 \%$ ) and URS Corona cultivars ( $X_{O}=6.17$ and $C V \times O=13.79 \%$ ) on the date 2 , and in the URS Taura $\left(X_{O}=5.66\right.$ and $C V X_{0}$ $=12.67 \%$ ) and URS Estampa cultivars ( $X_{O}=5.55$ and $C V \times O=12.41 \%$ ) on the date 3 . The sowing dates also differ significantly among themselves, with higher values on dates 2 ( $X_{0}=4.94$ and $\mathrm{CVXO}=11.05 \%)$ and $3(\mathrm{XO}=4.71$ and $\mathrm{CVxO}=$ $10.52 \%)$, without a significant difference among themselves, however, higher than the date 1 ( $X O=4.27$ and $C V \times O=9.55 \%$ ) in the URS Charrua cultivar, and on the date $2\left(\mathrm{XO}_{\mathrm{O}}=617\right.$ and $\mathrm{CV} \times \mathrm{XO}=$ $13.79 \%$ ) in the URS Corona cultivar (Table 1).

Concerning the measurement of dry matter, the means of the optimum plot size ( $\mathrm{XO}_{\mathrm{O}}$ ) and the coefficient of variation of the optimum plot size $(C \vee \times O)$ also differed, with higher values of $X_{O}=6.93$ and $C V x O=15.50 \%$ in the URS Taura cultivar, sown on the date 1 , of $X_{0}=6.28$ and 6.42, and $C V \times O=14.03 \%$ and $14.36 \%$ in the URS Taura and URS Corona cultivars, respectively, sown on the date 2 . The highest values among the sowing dates were obtained on dates 2 and 3, when the URS Charrua, URS Estampa and URS Corona cultivars were sown (Table 1).

Another finding was that the largest optimum plot size obtained to evaluate the fresh and the dry matter of oat was 6.62 and 6.93 basic experimental units of $0.25 \mathrm{~m} 2(1.66 \mathrm{~m} 2$ and $1.73 \mathrm{~m} 2)$, respectively, and the coefficient of variation of the optimum plot size was $14.80 \%$ and $15.50 \%$, respectively (Table 1). These values were considered adequate, for they encompass all the variability existent among the cultivars and the sowing dates.

\section{Number of replications}

In scenarios formed by combinations of $\mathrm{i}$ treatments $(i=3,4, \ldots, 50)$ and minimal differences among the treatment means to be detected as significant at a $5 \%$ probability by the Tukey test, expressed in percentage of the experiment mean $(d=10 \%, 15 \%, 20 \%, 25 \%, 30 \%, 35 \%, 40 \%$, $45 \%$ and $50 \%$ ), to evaluate the fresh matter of oat in the completely randomized design (CRD), the number of replications oscillated from 2.34 (i $=3$ and $d=50 \%$ ) to $69.96(i=50$ and $d=10 \%$ )
(Table 2) and in the randomized blocks design (RBD) they oscillated from $2.44(\mathrm{i}=3$ and $\mathrm{d}$ $=50 \%$ ) to $69.96(i=50$ and $d=10 \%$ ) (Table 3). Regarding the measurement of dry matter of oat in the completely randomized design (CRD), the number of replications ranged from $2.40(i=3$ and $d=50 \%$ ) to 76.72 ( $i=50$ and $d=10 \%$ ) (Table 4) and in the randomized blocks design (RBD) they ranged from $2.50(d=3 i=50 \%)$ to $76.72(i=$ 50 and $d=10 \%$ ) (Table 5).

In experiments with 50 treatments and higher experimental precision ( $d=10 \%)$, the required number of replications is the same in the completely randomized design and in the randomized blocks design, i.e., 69.96 and 76.72 replications for the measurement of fresh and dry matter, respectively. Thus, due to the high number of replications these experiments are not feasible. Nevertheless, whoever uses the information of this study can choose the combination of experimental design, number of treatments, minimal differences among the treatment means and the number of replications suitable to carry out one's experiment (Tables 2, 3, 4 and 5). It is important to note that the information provided on this study is from the $X_{0}$ and $\mathrm{CVX}$ o defined according to Paranaiba et al. (2009) methodology. Although the gain in the accuracy from the increasing of the $\mathrm{X}_{\mathrm{O}}$ is not very expressive, it is possible to opt for the increasing of the Xo to reduce the CVXo, and, thus, improve the experimental accuracy.

By fixing $X_{O}, C V X o$ and $d$, with the increase of the number of treatments, regardless of the experimental design CRD or RBD, the number of replications increases, as was also confirmed by Cargnelutti Filho et al. (2014a) (Tables 2, 3, 4 and 5). Furthermore, with the increase of the number of treatments, the number of replications for RBD and for CRD get closer. For fixed values of $X_{O}$, $C V X_{O}$, $i$ and $d$, the number of replications in the RBD is higher than the number of replications in the CRD, which confirms a higher efficiency of the CRD in relation to the RBD when there is no variability in the experimental units (plots) (Storck et al., 2016).

Thus, to evaluate a large number of treatments $(i=50)$ and $d=45 \%, 3.63$ replications in CRD and in RBD are required for 
Table 2. Number of replications to evaluate the aerial part of fresh matter of oat (Avena sativa L.), in a completely randomized design experiment, in scenarios formed by combinations of $i$ treatments $(i=3,4, \ldots, 50)$ and $d$ minimum differences among treatment means to be detected as significant at a $5 \%$ probability, using the Tukey test, expressed in percentage of the experiment mean ( $d=10 \%, 15 \%, 20 \%, 25 \%, 30 \%, 35 \%, 40 \%, 45 \%$ e $50 \%$ ), from the optimum plot size $\left(\mathrm{Xo}_{\mathrm{O}}=1.66 \mathrm{~m}^{2}\right)$ and the coefficient of variation of the optimum plot size $\left(\mathrm{CV}_{\mathrm{x}_{\mathrm{o}}}=14.80 \%\right)$

\begin{tabular}{|c|c|c|c|c|c|c|c|c|c|}
\hline i & $10 \%$ & $15 \%$ & $20 \%$ & $25 \%$ & $30 \%$ & $35 \%$ & $40 \%$ & $45 \%$ & $50 \%$ \\
\hline 3 & 25.08 & 11.75 & 7.11 & 4.99 & 3.86 & 3.19 & 2.82 & 2.59 & 2.34 \\
\hline 4 & 29.77 & 13.73 & 8.14 & 5.58 & 4.20 & 3.40 & 2.88 & 2.60 & 2.34 \\
\hline 5 & 33.34 & 15.25 & 8.94 & 6.04 & 4.48 & 3.55 & 2.98 & 2.61 & 2.36 \\
\hline 6 & 36.24 & 16.49 & 9.59 & 6.42 & 4.71 & 3.70 & 3.06 & 2.63 & 2.37 \\
\hline 7 & 38.67 & 17.53 & 10.15 & 6.74 & 4.91 & 3.82 & 3.13 & 2.67 & 2.39 \\
\hline 8 & 40.78 & 18.44 & 10.63 & 7.03 & 5.09 & 3.94 & 3.20 & 2.71 & 2.38 \\
\hline 9 & 42.64 & 19.24 & 11.06 & 7.29 & 5.25 & 4.04 & 3.26 & 2.75 & 2.39 \\
\hline 10 & 44.31 & 19.96 & 11.45 & 7.52 & 5.40 & 4.13 & 3.33 & 2.78 & 2.41 \\
\hline 11 & 45.82 & 20.61 & 11.80 & 7.73 & 5.53 & 4.22 & 3.38 & 2.82 & 2.43 \\
\hline 12 & 47.19 & 21.21 & 12.12 & 7.93 & 5.66 & 4.30 & 3.44 & 2.85 & 2.45 \\
\hline 13 & 48.46 & 21.76 & 12.42 & 8.11 & 5.78 & 4.38 & 3.49 & 2.89 & 2.47 \\
\hline 14 & 49.63 & 22.27 & 12.70 & 8.28 & 5.89 & 4.45 & 3.54 & 2.92 & 2.49 \\
\hline 15 & 50.72 & 22.74 & 12.96 & 8.43 & 5.99 & 4.52 & 3.58 & 2.95 & 2.51 \\
\hline 16 & 51.75 & 23.19 & 13.20 & 8.58 & 6.08 & 4.59 & 3.63 & 2.98 & 2.53 \\
\hline 17 & 52.71 & 23.61 & 13.43 & 8.72 & 6.18 & 4.65 & 3.67 & 3.01 & 2.55 \\
\hline 18 & 53.62 & 24.00 & 13.64 & 8.86 & 6.26 & 4.71 & 3.71 & 3.03 & 2.56 \\
\hline 19 & 54.48 & 24.38 & 13.85 & 8.98 & 6.35 & 4.77 & 3.75 & 3.06 & 2.58 \\
\hline 20 & 55.29 & 24.73 & 14.04 & 9.10 & 6.42 & 4.82 & 3.79 & 3.09 & 2.60 \\
\hline 21 & 56.07 & 25.07 & 14.23 & 9.22 & 6.50 & 4.87 & 3.82 & 3.11 & 2.61 \\
\hline 22 & 56.81 & 25.40 & 14.41 & 9.33 & 6.57 & 4.92 & 3.86 & 3.14 & 2.63 \\
\hline 23 & 57.52 & 25.71 & 14.58 & 9.43 & 6.64 & 4.97 & 3.89 & 3.16 & 2.65 \\
\hline 24 & 58.20 & 26.00 & 14.74 & 9.53 & 6.71 & 5.02 & 3.92 & 3.18 & 2.66 \\
\hline 25 & 58.85 & 26.29 & 14.90 & 9.63 & 6.77 & 5.06 & 3.95 & 3.21 & 2.68 \\
\hline 26 & 59.47 & 26.56 & 15.05 & 9.72 & 6.84 & 5.10 & 3.99 & 3.23 & 2.69 \\
\hline 27 & 60.08 & 26.83 & 15.19 & 9.81 & 6.90 & 5.15 & 4.01 & 3.25 & 2.71 \\
\hline 28 & 60.66 & 27.08 & 15.33 & 9.90 & 6.96 & 5.19 & 4.04 & 3.27 & 2.72 \\
\hline 29 & 61.22 & 27.33 & 15.47 & 9.99 & 7.01 & 5.22 & 4.07 & 3.29 & 2.74 \\
\hline 30 & 61.76 & 27.56 & 15.60 & 10.07 & 7.07 & 5.26 & 4.10 & 3.31 & 2.75 \\
\hline 31 & 62.29 & 27.80 & 15.73 & 10.15 & 7.12 & 5.30 & 4.13 & 3.33 & 2.76 \\
\hline 32 & 62.79 & 28.02 & 15.85 & 10.22 & 7.17 & 5.34 & 4.15 & 3.35 & 2.78 \\
\hline 33 & 63.29 & 28.23 & 15.97 & 10.30 & 7.22 & 5.37 & 4.18 & 3.36 & 2.79 \\
\hline 34 & 63.76 & 28.44 & 16.09 & 10.37 & 7.27 & 5.41 & 4.20 & 3.38 & 2.80 \\
\hline 35 & 64.23 & 28.65 & 16.20 & 10.44 & 7.32 & 5.44 & 4.23 & 3.40 & 2.82 \\
\hline 36 & 64.68 & 28.85 & 16.31 & 10.51 & 7.36 & 5.47 & 4.25 & 3.42 & 2.83 \\
\hline 37 & 65.12 & 29.04 & 16.42 & 10.58 & 7.41 & 5.50 & 4.27 & 3.43 & 2.84 \\
\hline 38 & 65.55 & 29.23 & 16.52 & 10.64 & 7.45 & 5.53 & 4.29 & 3.45 & 2.85 \\
\hline 39 & 65.96 & 29.41 & 16.62 & 10.70 & 7.49 & 5.56 & 4.32 & 3.47 & 2.87 \\
\hline 40 & 66.37 & 29.59 & 16.72 & 10.77 & 7.54 & 5.59 & 4.34 & 3.48 & 2.88 \\
\hline 41 & 66.77 & 29.76 & 16.82 & 10.83 & 7.58 & 5.62 & 4.36 & 3.50 & 2.89 \\
\hline 42 & 67.15 & 29.94 & 16.91 & 10.89 & 7.62 & 5.65 & 4.38 & 3.51 & 2.90 \\
\hline 43 & 67.53 & 30.10 & 17.00 & 10.94 & 7.66 & 5.68 & 4.40 & 3.53 & 2.91 \\
\hline 44 & 67.90 & 30.26 & 17.09 & 11.00 & 7.69 & 5.71 & 4.42 & 3.54 & 2.92 \\
\hline 45 & 68.26 & 30.42 & 17.18 & 11.06 & 7.73 & 5.73 & 4.44 & 3.56 & 2.93 \\
\hline 46 & 68.62 & 30.58 & 17.27 & 11.11 & 7.77 & 5.76 & 4.46 & 3.57 & 2.94 \\
\hline 47 & 68.96 & 30.73 & 17.35 & 11.16 & 7.80 & 5.78 & 4.48 & 3.58 & 2.95 \\
\hline 48 & 69.30 & 30.88 & 17.44 & 11.22 & 7.84 & 5.81 & 4.49 & 3.60 & 2.96 \\
\hline 49 & 69.63 & 31.03 & 17.52 & 11.27 & 7.87 & 5.83 & 4.51 & 3.61 & 2.97 \\
\hline 50 & 69.96 & 31.17 & 17.60 & 11.32 & 7.91 & 5.86 & 4.53 & 3.62 & 2.98 \\
\hline
\end{tabular}

the measurement of fresh matter (tables 2 and 3) and 3.96 replications for the measurement of dry matter (Tables 4 and 5). In practice, in field experiments these values cannot be used, then the right action to follow is to round them, using four replications to measure fresh and dry matter of oat. It is possible to calculate the minimum significant difference (d) of the Tukey 
Table 3. Number of replications to evaluate the aerial part of fresh matter of oat (Avena sativa L.), in a randomized blocks design experiment, in scenarios formed by combinations of $i$ treatments $(i=3,4, \ldots 50)$ and $d$ minimum differences among treatment means to be detected as significant at a $5 \%$ probability, using the Tukey test, expressed in percentage of the experiment mean ( $d=10 \%, 15 \%, 20 \%, 25 \%, 30 \%, 35 \%, 40 \%, 45 \%$ and $50 \%)$, from the optimum plot size ( $\mathrm{XO}=1.66 \mathrm{~m} 2)$ and the coefficient of variation of the optimum plot size $(\mathrm{CVXO}=14.80 \%)$

\begin{tabular}{|c|c|c|c|c|c|c|c|c|c|}
\hline i & $10 \%$ & $15 \%$ & $20 \%$ & $25 \%$ & $30 \%$ & $35 \%$ & $40 \%$ & $45 \%$ & $50 \%$ \\
\hline 3 & 25.58 & 12.25 & 7.59 & 5.46 & 4.32 & 3.33 & 3.08 & 2.73 & 2.44 \\
\hline 4 & 30.05 & 14.02 & 8.43 & 5.86 & 4.48 & 3.65 & 3.10 & 2.74 & 2.45 \\
\hline 5 & 33.53 & 15.44 & 9.12 & 6.22 & 4.67 & 3.74 & 3.14 & 2.75 & 2.45 \\
\hline 6 & 36.37 & 16.62 & 9.72 & 6.55 & 4.84 & 3.83 & 3.18 & 2.76 & 2.46 \\
\hline 7 & 38.77 & 17.63 & 10.25 & 6.85 & 5.02 & 3.93 & 3.23 & 2.77 & 2.46 \\
\hline 8 & 40.86 & 18.52 & 10.71 & 7.11 & 5.17 & 4.02 & 3.28 & 2.79 & 2.46 \\
\hline 9 & 42.71 & 19.30 & 11.12 & 7.35 & 5.32 & 4.10 & 3.33 & 2.82 & 2.46 \\
\hline 10 & 44.36 & 20.01 & 11.50 & 7.57 & 5.45 & 4.19 & 3.38 & 2.84 & 2.47 \\
\hline 11 & 45.86 & 20.65 & 11.84 & 7.78 & 5.58 & 4.27 & 3.43 & 2.87 & 2.48 \\
\hline 12 & 47.23 & 21.24 & 12.16 & 7.97 & 5.70 & 4.34 & 3.48 & 2.89 & 2.49 \\
\hline 13 & 48.49 & 21.79 & 12.45 & 8.14 & 5.81 & 4.42 & 3.52 & 2.92 & 2.51 \\
\hline 14 & 49.66 & 22.29 & 12.73 & 8.31 & 5.91 & 4.48 & 3.57 & 2.95 & 2.52 \\
\hline 15 & 50.75 & 22.77 & 12.98 & 8.46 & 6.01 & 4.55 & 3.61 & 2.98 & 2.54 \\
\hline 16 & 51.77 & 23.21 & 13.22 & 8.61 & 6.11 & 4.61 & 3.65 & 3.00 & 2.55 \\
\hline 17 & 52.73 & 23.63 & 13.45 & 8.74 & 6.20 & 4.67 & 3.69 & 3.03 & 2.57 \\
\hline 18 & 53.64 & 24.02 & 13.66 & 8.87 & 6.28 & 4.73 & 3.73 & 3.06 & 2.58 \\
\hline 19 & 54.49 & 24.39 & 13.86 & 9.00 & 6.36 & 4.78 & 3.77 & 3.08 & 2.60 \\
\hline 20 & 55.31 & 24.75 & 14.06 & 9.12 & 6.44 & 4.84 & 3.80 & 3.10 & 2.62 \\
\hline 21 & 56.08 & 25.09 & 14.24 & 9.23 & 6.52 & 4.89 & 3.84 & 3.13 & 2.63 \\
\hline 22 & 56.82 & 25.41 & 14.42 & 9.34 & 6.59 & 4.93 & 3.87 & 3.15 & 2.65 \\
\hline 23 & 57.53 & 25.72 & 14.59 & 9.44 & 6.66 & 4.98 & 3.90 & 3.17 & 2.66 \\
\hline 24 & 58.21 & 26.01 & 14.75 & 9.54 & 6.72 & 5.03 & 3.94 & 3.20 & 2.68 \\
\hline 25 & 58.86 & 26.30 & 14.91 & 9.64 & 6.79 & 5.07 & 3.97 & 3.22 & 2.69 \\
\hline 26 & 59.48 & 26.57 & 15.06 & 9.73 & 6.85 & 5.11 & 4.00 & 3.24 & 2.70 \\
\hline 27 & 60.08 & 26.84 & 15.20 & 9.82 & 6.91 & 5.15 & 4.02 & 3.26 & 2.72 \\
\hline 28 & 60.67 & 27.09 & 15.34 & 9.91 & 6.96 & 5.19 & 4.05 & 3.28 & 2.73 \\
\hline 29 & 61.23 & 27.33 & 15.48 & 9.99 & 7.02 & 5.23 & 4.08 & 3.30 & 2.75 \\
\hline 30 & 61.77 & 27.57 & 15.61 & 10.07 & 7.07 & 5.27 & 4.11 & 3.32 & 2.76 \\
\hline 31 & 62.29 & 27.80 & 15.73 & 10.15 & 7.13 & 5.31 & 4.13 & 3.34 & 2.77 \\
\hline 32 & 62.80 & 28.02 & 15.86 & 10.23 & 7.18 & 5.34 & 4.16 & 3.35 & 2.79 \\
\hline 33 & 63.29 & 28.24 & 15.98 & 10.30 & 7.23 & 5.38 & 4.18 & 3.37 & 2.80 \\
\hline 34 & 63.77 & 28.45 & 16.09 & 10.38 & 7.28 & 5.41 & 4.21 & 3.39 & 2.81 \\
\hline 35 & 64.23 & 28.65 & 16.20 & 10.45 & 7.32 & 5.44 & 4.23 & 3.41 & 2.82 \\
\hline 36 & 64.69 & 28.85 & 16.31 & 10.51 & 7.37 & 5.48 & 4.25 & 3.42 & 2.84 \\
\hline 37 & 65.12 & 29.05 & 16.42 & 10.58 & 7.41 & 5.51 & 4.28 & 3.44 & 2.85 \\
\hline 38 & 65.55 & 29.23 & 16.52 & 10.65 & 7.46 & 5.54 & 4.30 & 3.46 & 2.86 \\
\hline 39 & 65.97 & 29.42 & 16.63 & 10.71 & 7.50 & 5.57 & 4.32 & 3.47 & 2.87 \\
\hline 40 & 66.38 & 29.59 & 16.72 & 10.77 & 7.54 & 5.60 & 4.34 & 3.49 & 2.88 \\
\hline 41 & 66.77 & 29.77 & 16.82 & 10.83 & 7.58 & 5.63 & 4.36 & 3.50 & 2.89 \\
\hline 42 & 67.16 & 29.94 & 16.92 & 10.89 & 7.62 & 5.65 & 4.38 & 3.52 & 2.90 \\
\hline 43 & 67.54 & 30.11 & 17.01 & 10.95 & 7.66 & 5.68 & 4.40 & 3.53 & 2.92 \\
\hline 44 & 67.91 & 30.27 & 17.10 & 11.00 & 7.70 & 5.71 & 4.42 & 3.55 & 2.93 \\
\hline 45 & 68.27 & 30.43 & 17.19 & 11.06 & 7.74 & 5.74 & 4.44 & 3.56 & 2.94 \\
\hline 46 & 68.62 & 30.58 & 17.27 & 11.11 & 7.77 & 5.76 & 4.46 & 3.57 & 2.95 \\
\hline 47 & 68.97 & 30.73 & 17.36 & 11.17 & 7.81 & 5.79 & 4.48 & 3.59 & 2.96 \\
\hline 48 & 69.31 & 30.88 & 17.44 & 11.22 & 7.84 & 5.81 & 4.50 & 3.60 & 2.97 \\
\hline 49 & 69.64 & 31.03 & 17.52 & 11.27 & 7.88 & 5.84 & 4.52 & 3.62 & 2.98 \\
\hline 50 & 69.96 & 31.17 & 17.60 & 11.32 & 7.91 & 5.86 & 4.53 & 3.63 & 2.99 \\
\hline
\end{tabular}

test, expressed in percentage of the experiment mean with the expression

$$
d=q_{a(i ; G L E)} C V / \sqrt{r}
$$

with $\mathrm{i}=50$ treatments, $\mathrm{a}=0.05, \mathrm{CVXO}=$ $14.80 \%$ and $15.50 \%$ (coefficient of variation of the optimum plot size) to fresh and dry matter, respectively, and $r=4$ replications. In these conditions, it was obtained for the fresh matter $d$ $=42.71 \%$ in a completely randomized design and $d=42.73 \%$ in a randomized blocks design. As for the dry matter, $d=44.73 \%$ was determined in a completely randomized design and $d=44.75 \%$, in a randomized blocks design. 
Table 4. Number of replications to evaluate the aerial part of dry matter of oat (Avena sativa L.), in a completely randomized design experiment, in scenarios formed by combinations of $i$ treatments $(i=3,4, \ldots, 50)$ and $d$ minimum differences among treatment means to be detected as significant at a $5 \%$ probability, using the Tukey test, expressed in percentage of the experiment mean ( $d=10 \%, 15 \%, 20 \%, 25 \%, 30 \%, 35 \%, 40 \%, 45 \%$ and $50 \%)$, from the optimum plot size $\left(\mathrm{Xo}_{\mathrm{O}}=1.73 \mathrm{~m}^{2}\right)$ and the coefficient of variation of the optimum plot size $\left(\mathrm{CV}_{\mathrm{x}_{\mathrm{o}}}=15.50 \%\right)$

\begin{tabular}{|c|c|c|c|c|c|c|c|c|c|}
\hline i & $10 \%$ & $15 \%$ & $20 \%$ & $25 \%$ & $30 \%$ & $35 \%$ & $40 \%$ & $45 \%$ & $50 \%$ \\
\hline 3 & 27.41 & 12.78 & 7.68 & 5.35 & 4.10 & 3.36 & 2.98 & 2.70 & 2.40 \\
\hline 4 & 32.57 & 14.97 & 8.84 & 6.02 & 4.50 & 3.61 & 3.05 & 2.73 & 2.45 \\
\hline 5 & 36.50 & 16.65 & 9.72 & 6.54 & 4.82 & 3.80 & 3.15 & 2.72 & 2.47 \\
\hline 6 & 39.68 & 18.02 & 10.45 & 6.96 & 5.08 & 3.97 & 3.26 & 2.79 & 2.49 \\
\hline 7 & 42.36 & 19.17 & 11.07 & 7.33 & 5.31 & 4.11 & 3.35 & 2.84 & 2.48 \\
\hline 8 & 44.68 & 20.17 & 11.60 & 7.65 & 5.52 & 4.24 & 3.43 & 2.89 & 2.51 \\
\hline 9 & 46.73 & 21.05 & 12.08 & 7.94 & 5.70 & 4.36 & 3.51 & 2.93 & 2.53 \\
\hline 10 & 48.55 & 21.85 & 12.51 & 8.19 & 5.86 & 4.47 & 3.58 & 2.98 & 2.56 \\
\hline 11 & 50.21 & 22.56 & 12.90 & 8.43 & 6.02 & 4.57 & 3.65 & 3.02 & 2.59 \\
\hline 12 & 51.72 & 23.22 & 13.25 & 8.65 & 6.16 & 4.67 & 3.71 & 3.07 & 2.62 \\
\hline 13 & 53.11 & 23.82 & 13.58 & 8.85 & 6.29 & 4.75 & 3.77 & 3.10 & 2.64 \\
\hline 14 & 54.40 & 24.39 & 13.89 & 9.04 & 6.41 & 4.84 & 3.82 & 3.14 & 2.67 \\
\hline 15 & 55.60 & 24.91 & 14.17 & 9.21 & 6.52 & 4.91 & 3.88 & 3.18 & 2.69 \\
\hline 16 & 56.73 & 25.40 & 14.44 & 9.38 & 6.63 & 4.99 & 3.93 & 3.21 & 2.71 \\
\hline 17 & 57.78 & 25.86 & 14.69 & 9.53 & 6.74 & 5.06 & 3.98 & 3.25 & 2.73 \\
\hline 18 & 58.78 & 26.30 & 14.93 & 9.68 & 6.83 & 5.12 & 4.02 & 3.28 & 2.76 \\
\hline 19 & 59.72 & 26.71 & 15.16 & 9.82 & 6.93 & 5.19 & 4.07 & 3.31 & 2.78 \\
\hline 20 & 60.62 & 27.10 & 15.37 & 9.95 & 7.01 & 5.25 & 4.11 & 3.34 & 2.80 \\
\hline 21 & 61.47 & 27.47 & 15.58 & 10.08 & 7.10 & 5.31 & 4.15 & 3.37 & 2.82 \\
\hline 22 & 62.29 & 27.83 & 15.77 & 10.20 & 7.18 & 5.36 & 4.19 & 3.40 & 2.84 \\
\hline 23 & 63.06 & 28.17 & 15.96 & 10.32 & 7.26 & 5.42 & 4.23 & 3.43 & 2.86 \\
\hline 24 & 63.81 & 28.50 & 16.14 & 10.43 & 7.33 & 5.47 & 4.27 & 3.45 & 2.88 \\
\hline 25 & 64.52 & 28.81 & 16.31 & 10.54 & 7.40 & 5.52 & 4.30 & 3.48 & 2.89 \\
\hline 26 & 65.21 & 29.11 & 16.48 & 10.64 & 7.47 & 5.57 & 4.34 & 3.50 & 2.91 \\
\hline 27 & 65.87 & 29.40 & 16.64 & 10.74 & 7.54 & 5.61 & 4.37 & 3.53 & 2.93 \\
\hline 28 & 66.51 & 29.68 & 16.80 & 10.84 & 7.60 & 5.66 & 4.40 & 3.55 & 2.95 \\
\hline 29 & 67.13 & 29.95 & 16.95 & 10.93 & 7.67 & 5.70 & 4.44 & 3.57 & 2.96 \\
\hline 30 & 67.72 & 30.21 & 17.09 & 11.02 & 7.73 & 5.75 & 4.47 & 3.60 & 2.98 \\
\hline 31 & 68.30 & 30.47 & 17.23 & 11.11 & 7.79 & 5.79 & 4.50 & 3.62 & 3.00 \\
\hline 32 & 68.85 & 30.71 & 17.37 & 11.19 & 7.84 & 5.83 & 4.53 & 3.64 & 3.01 \\
\hline 33 & 69.40 & 30.95 & 17.50 & 11.27 & 7.90 & 5.87 & 4.55 & 3.66 & 3.03 \\
\hline 34 & 69.92 & 31.18 & 17.62 & 11.35 & 7.95 & 5.90 & 4.58 & 3.68 & 3.04 \\
\hline 35 & 70.43 & 31.40 & 17.75 & 11.43 & 8.00 & 5.94 & 4.61 & 3.70 & 3.06 \\
\hline 36 & 70.93 & 31.62 & 17.87 & 11.51 & 8.06 & 5.98 & 4.63 & 3.72 & 3.07 \\
\hline 37 & 71.41 & 31.83 & 17.99 & 11.58 & 8.10 & 6.01 & 4.66 & 3.74 & 3.09 \\
\hline 38 & 71.88 & 32.04 & 18.10 & 11.65 & 8.15 & 6.05 & 4.69 & 3.76 & 3.10 \\
\hline 39 & 72.34 & 32.24 & 18.21 & 11.72 & 8.20 & 6.08 & 4.71 & 3.78 & 3.11 \\
\hline 40 & 72.78 & 32.44 & 18.32 & 11.79 & 8.25 & 6.11 & 4.73 & 3.79 & 3.13 \\
\hline 41 & 73.22 & 32.63 & 18.43 & 11.86 & 8.29 & 6.15 & 4.76 & 3.81 & 3.14 \\
\hline 42 & 73.64 & 32.82 & 18.53 & 11.92 & 8.34 & 6.18 & 4.78 & 3.83 & 3.15 \\
\hline 43 & 74.06 & 33.00 & 18.63 & 11.99 & 8.38 & 6.21 & 4.80 & 3.84 & 3.16 \\
\hline 44 & 74.46 & 33.18 & 18.73 & 12.05 & 8.42 & 6.24 & 4.83 & 3.86 & 3.18 \\
\hline 45 & 74.86 & 33.35 & 18.83 & 12.11 & 8.46 & 6.27 & 4.85 & 3.88 & 3.19 \\
\hline 46 & 75.25 & 33.53 & 18.93 & 12.17 & 8.50 & 6.30 & 4.87 & 3.89 & 3.20 \\
\hline 47 & 75.63 & 33.69 & 19.02 & 12.23 & 8.54 & 6.32 & 4.89 & 3.91 & 3.21 \\
\hline 48 & 76.00 & 33.86 & 19.11 & 12.29 & 8.58 & 6.35 & 4.91 & 3.92 & 3.22 \\
\hline 49 & 76.36 & 34.02 & 19.20 & 12.34 & 8.62 & 6.38 & 4.93 & 3.94 & 3.24 \\
\hline 50 & 76.72 & 34.17 & 19.29 & 12.40 & 8.66 & 6.41 & 4.95 & 3.95 & 3.25 \\
\hline
\end{tabular}


Table 5. Number of replications to evaluate the aerial part of dry matter of oat (Avena sativa L.), in a randomized blocks design experiment, in scenarios formed by combinations of $i$ treatments $(i=3,4 \ldots, 50)$ and $d$ minimum differences among treatment means to be detected as significant at a $5 \%$ probability, using the Tukey test, expressed in percentage of the experiment mean ( $d=10 \%, 15 \%, 20 \%, 25 \%, 30 \%, 35 \%, 40 \%, 45 \%$ and $50 \%)$, from the optimum plot size $\left(\mathrm{Xo}_{\mathrm{O}}=1.73 \mathrm{~m}^{2}\right)$ and the coefficient of variation of the optimum plot size $\left(\mathrm{CV}_{\mathrm{x}_{\mathrm{o}}}=15.50 \%\right)$

\begin{tabular}{|c|c|c|c|c|c|c|c|c|c|}
\hline i & $10 \%$ & $15 \%$ & $20 \%$ & $25 \%$ & $30 \%$ & $35 \%$ & $40 \%$ & $45 \%$ & $50 \%$ \\
\hline 3 & 27.91 & 13.28 & 8.18 & 5.84 & 4.57 & 3.69 & 3.20 & 2.90 & 2.50 \\
\hline 4 & 32.85 & 15.26 & 9.12 & 6.29 & 4.78 & 3.88 & 3.27 & 2.91 & 2.55 \\
\hline 5 & 36.68 & 16.84 & 9.91 & 6.72 & 5.00 & 3.99 & 3.33 & 2.93 & 2.58 \\
\hline 6 & 39.81 & 18.15 & 10.58 & 7.10 & 5.22 & 4.10 & 3.39 & 2.92 & 2.64 \\
\hline 7 & 42.46 & 19.27 & 11.17 & 7.43 & 5.41 & 4.21 & 3.45 & 2.94 & 2.59 \\
\hline 8 & 44.76 & 20.25 & 11.68 & 7.73 & 5.60 & 4.33 & 3.51 & 2.97 & 2.59 \\
\hline 9 & 46.79 & 21.12 & 12.14 & 8.00 & 5.76 & 4.43 & 3.57 & 3.00 & 2.60 \\
\hline 10 & 48.61 & 21.90 & 12.56 & 8.25 & 5.92 & 4.53 & 3.63 & 3.03 & 2.62 \\
\hline 11 & 50.25 & 22.61 & 12.94 & 8.48 & 6.06 & 4.62 & 3.69 & 3.07 & 2.64 \\
\hline 12 & 51.76 & 23.26 & 13.29 & 8.69 & 6.20 & 4.71 & 3.75 & 3.11 & 2.66 \\
\hline 13 & 53.14 & 23.86 & 13.61 & 8.88 & 6.32 & 4.79 & 3.80 & 3.14 & 2.68 \\
\hline 14 & 54.43 & 24.41 & 13.92 & 9.07 & 6.44 & 4.87 & 3.86 & 3.17 & 2.70 \\
\hline 15 & 55.63 & 24.93 & 14.20 & 9.24 & 6.55 & 4.94 & 3.91 & 3.21 & 2.72 \\
\hline 16 & 56.75 & 25.42 & 14.46 & 9.40 & 6.66 & 5.01 & 3.95 & 3.24 & 2.74 \\
\hline 17 & 57.80 & 25.88 & 14.71 & 9.55 & 6.76 & 5.08 & 4.00 & 3.27 & 2.76 \\
\hline 18 & 58.80 & 26.31 & 14.95 & 9.70 & 6.85 & 5.14 & 4.04 & 3.30 & 2.78 \\
\hline 19 & 59.74 & 26.72 & 15.17 & 9.84 & 6.94 & 5.21 & 4.09 & 3.33 & 2.80 \\
\hline 20 & 60.63 & 27.11 & 15.39 & 9.97 & 7.03 & 5.26 & 4.13 & 3.36 & 2.82 \\
\hline 21 & 61.49 & 27.49 & 15.59 & 10.09 & 7.11 & 5.32 & 4.17 & 3.38 & 2.84 \\
\hline 22 & 62.30 & 27.84 & 15.79 & 10.21 & 7.19 & 5.38 & 4.21 & 3.41 & 2.85 \\
\hline 23 & 63.07 & 28.18 & 15.97 & 10.33 & 7.27 & 5.43 & 4.24 & 3.44 & 2.87 \\
\hline 24 & 63.82 & 28.51 & 16.15 & 10.44 & 7.34 & 5.48 & 4.28 & 3.46 & 2.89 \\
\hline 25 & 64.53 & 28.82 & 16.32 & 10.55 & 7.41 & 5.53 & 4.31 & 3.49 & 2.91 \\
\hline 26 & 65.22 & 29.12 & 16.49 & 10.65 & 7.48 & 5.58 & 4.35 & 3.51 & 2.92 \\
\hline 27 & 65.88 & 29.41 & 16.65 & 10.75 & 7.55 & 5.62 & 4.38 & 3.54 & 2.94 \\
\hline 28 & 66.52 & 29.69 & 16.80 & 10.84 & 7.61 & 5.67 & 4.41 & 3.56 & 2.96 \\
\hline 29 & 67.13 & 29.96 & 16.95 & 10.94 & 7.67 & 5.71 & 4.44 & 3.58 & 2.97 \\
\hline 30 & 67.73 & 30.22 & 17.10 & 11.03 & 7.73 & 5.75 & 4.47 & 3.60 & 2.99 \\
\hline 31 & 68.30 & 30.47 & 17.24 & 11.11 & 7.79 & 5.79 & 4.50 & 3.63 & 3.00 \\
\hline 32 & 68.86 & 30.72 & 17.37 & 11.20 & 7.85 & 5.83 & 4.53 & 3.65 & 3.02 \\
\hline 33 & 69.40 & 30.96 & 17.50 & 11.28 & 7.90 & 5.87 & 4.56 & 3.67 & 3.03 \\
\hline 34 & 69.93 & 31.19 & 17.63 & 11.36 & 7.96 & 5.91 & 4.59 & 3.69 & 3.05 \\
\hline 35 & 70.44 & 31.41 & 17.75 & 11.44 & 8.01 & 5.95 & 4.61 & 3.71 & 3.06 \\
\hline 36 & 70.93 & 31.63 & 17.87 & 11.51 & 8.06 & 5.98 & 4.64 & 3.73 & 3.08 \\
\hline 37 & 71.41 & 31.84 & 17.99 & 11.59 & 8.11 & 6.02 & 4.67 & 3.74 & 3.09 \\
\hline 38 & 71.88 & 32.05 & 18.11 & 11.66 & 8.16 & 6.05 & 4.69 & 3.76 & 3.10 \\
\hline 39 & 72.34 & 32.25 & 18.22 & 11.73 & 8.21 & 6.09 & 4.72 & 3.78 & 3.12 \\
\hline 40 & 72.79 & 32.44 & 18.33 & 11.80 & 8.25 & 6.12 & 4.74 & 3.80 & 3.13 \\
\hline 41 & 73.22 & 32.64 & 18.43 & 11.86 & 8.30 & 6.15 & 4.76 & 3.82 & 3.14 \\
\hline 42 & 73.65 & 32.82 & 18.54 & 11.93 & 8.34 & 6.18 & 4.78 & 3.83 & 3.16 \\
\hline 43 & 74.06 & 33.00 & 18.64 & 11.99 & 8.38 & 6.21 & 4.81 & 3.85 & 3.17 \\
\hline 44 & 74.47 & 33.18 & 18.74 & 12.05 & 8.43 & 6.24 & 4.83 & 3.87 & 3.18 \\
\hline 45 & 74.86 & 33.36 & 18.83 & 12.11 & 8.47 & 6.27 & 4.85 & 3.88 & 3.19 \\
\hline 46 & 75.25 & 33.53 & 18.93 & 12.17 & 8.51 & 6.30 & 4.87 & 3.90 & 3.20 \\
\hline 47 & 75.63 & 33.70 & 19.02 & 12.23 & 8.55 & 6.33 & 4.89 & 3.91 & 3.22 \\
\hline 48 & 76.00 & 33.86 & 19.11 & 12.29 & 8.59 & 6.36 & 4.91 & 3.93 & 3.23 \\
\hline 49 & 76.37 & 34.02 & 19.20 & 12.35 & 8.62 & 6.38 & 4.93 & 3.94 & 3.24 \\
\hline 50 & 76.72 & 34.18 & 19.29 & 12.40 & 8.66 & 6.41 & 4.95 & 3.96 & 3.25 \\
\hline
\end{tabular}




\section{Discussion}

Descriptive statistics

Plot size studies with soil covering plants found scenarios with wide variability of statistics $\rho, s 2, m, C V$, Xo and CVXo among uniformity trials (Cargnelutti Filho et al., 2014a, Burin et al., 2015), as observed in this study. According to these authors, this scenario of variability is important in studies of optimum plot size and of number of replications, for it reflects real conditions of the field cultivation.

\section{Average fresh matter and dry matter}

Overall, the means of fresh and dry matter of oat in the four cultivars on the three sowing dates were respectively $0.68568 \mathrm{~kg} 0.25$ $\mathrm{m}^{-2}\left(27,430 \mathrm{~kg} \mathrm{ha}^{-1}\right)$ and $0.13541 \mathrm{~kg} 0.25 \mathrm{~m}^{-2}$ $\left(5,420 \mathrm{~kg} \mathrm{ha}^{-1}\right)$. These fresh and dry matter of oat productivities were inferior than $51,160 \mathrm{~kg} \mathrm{ha}^{-1}$ and $8,900 \mathrm{~kg} \mathrm{ha}^{-1}$, respectively, and were obtained in the labal et al. (2014) study. Values higher than the study of fresh and dry matter of $80,000 \mathrm{~kg}$ $\mathrm{ha}^{-1}$ and $10,950 \mathrm{~kg} \mathrm{ha}^{-1}$, respectively, were also observed by Khan et al. (2014). Lower values of fresh and dry matter of $5,150 \mathrm{~kg} \mathrm{ha}^{-1}$ and $1,170 \mathrm{~kg}$ $\mathrm{ha}^{-1}$, respectively, were obtained in the study of Grecco et al. (201 1). In Meinerz et al. study (2011), the authors obtained values of $33,280 \mathrm{~kg} \mathrm{ha}^{-1}$ for the fresh matter and of $11,910 \mathrm{~kg} \mathrm{ha}^{-1}$ for the dry matter of oat, which are higher than the values of this study. Higher values of fresh matter, 42,890 $\mathrm{kg} \mathrm{ha}^{-1}$, and of dry matter, 10,080 kg ha-1, were also verified by Floss et al. (2007). Differences in cultivation, climate, soil, management and sowing dates may explain the different results between the mentioned studies and the present study. Thus, it can be said that, in general, the cultivation had an adequate development and a high productive potential, reflecting the real conditions of the field. Furthermore, a set of substantial data $(3,456 \mathrm{BEU})$ with four cultivars in three sowing dates, and a wide variability scenario, give, combined with all of the above, credibility to the study of the dimensioning of the optimum plot size and the number of replications in oat cultivation.

\section{Coefficient of variation}

Coefficients of variation of this magnitude observed in the study are above the observed value of $8.52 \%$, present in a study conducted by Meinerz et al. (2011), which evaluates the production and the content of dry matter of oat. These values are also above the $14.91 \%$ coefficient of variation obtained by Floss et al. (2007) for the yield of dry matter of oat. It is also important to point out that these high values of the coefficient of variation obtained on this study may indicate low precision in conducting the experiment, however, these values are acceptable because the experiments conducted in the field usually exhibit higher estimates of the coefficient of variation, due to the less control of the experimental error (Smiderle et al., 2014).

Optimum plot size and coefficient of variation of optimum plot size

The purpose of the estimate portion size according to Frazer et al. (2011) is to minimize the experimental error, increase forecast accuracy and the variables and reduce the measurement effort. For this purpose was obtained optimum plot size in this study $X_{0}=1.66 \mathrm{~m} 2$ for fresh matter, and $X_{0}=1.73 \mathrm{~m} 2$ dry matter, which includes the maximum variability in this scenario (cultivars and seasons seeding), in which, from these values, the increase in variability is negligible. Still, it was found dissimilarity in estimating the optimum plot size between the mass variables of fresh and dry matter of oat. In a study by Lombardi et al. (2015) on the effect of plot size in the estimation of forest indicators was also observed difference between the estimated variables, which corroborates the information in this study.

Throughout the investigation of the literature, no studies were found on the dimensioning of the optimum plot size to assess the fresh matter ( $\mathrm{XO}=6.62 \mathrm{BEU}$ or $1,66 \mathrm{~m} 2$ and $\mathrm{CVxO}=14.80 \%)$ and the dry matter $(\mathrm{XO}=6.93$ BEU or $1.73 \mathrm{~m} 2$ and $C V x O=15.50 \%$ ) of oat to be faced with these data obtained on this study. Nevertheless, in cultivations from the same family (Poaceae), such as the black oat, Cargnelutti Filho et al. (2014a), in order to evaluate the fresh matter, defined Xo of $4.14 \mathrm{~m} 2$ and CVxo of $9.25 \%$, and to measure the fresh matter of millet, Burin et al. (2015) established Xo of $4.46 \mathrm{~m} 2$ and CVxo of 
9.96\%. Within this context, it was verified that in the evaluation of the aerial part of fresh matter of these cultivations, the estimates of $\mathrm{Xo}$ and $\mathrm{CVxO}$ were different. Therefore, it can be inferred that the use of the plot size of a certain cultivation when used in another cultivation may produce results with low experimental precision. In this case, when these crops are analyzed together, in the same experiment, it is suggested to scale the plot size based on the highest estimate in order to provide the desired accuracy for all the cultivations.

In studies that measure fresh and dry matter of oat, the plot sizes used by Floss et al. (2007), Grecco et al. (201 1), Demétrio et al. (2012) and Ferrazza et al. (2013), Khan et al. (2014) and lqbal et al. (2014) were larger than the plot size of this study, which suggests that the information attained on these studies were obtained from plots with sufficient size. However, on the studies of Tafernaberri Júnior et al. (2012), Meinerz et al. (2012) and Soares et al. (2013), the plot sizes were inferior to that obtained on the present study. The use of a smaller plot size than the optimal plot size may increase the experimental error, and thus conceal the effect of treatment. The comparison between the optimum size obtained on this study and the plot sizes used in the aforementioned studies should be considered with caution, for there are differences concerning the useable area of the plot used in the evaluations.

\section{Number of replications}

The number of repetitions determined to measure the fresh weight and dry matter of oat that study was replicated four times. Studies have been conducted with four (Demétrio et al., 2012; Tabernaberri Júnior et al., 2012; Soares et al., 2013) and three (Floss et al., 2007; Meinerz et al., 2012; Ferrazza et al., 2013; Khan et al., 2014; labal et al., 2014) replications, showing the feasibility of conducting experiments with these numbers of replications. A proper scaling of the plot size and the proper number of replications, as mentioned by Cargnelutti Filho et al. (2014b), is critical to perform accurate inferences in the experiments.

Can infer that to evaluate the aerial part of fresh and dry matter of oat in a CRD or a $\mathrm{RBD}$, with the maximum of 50 treatments, using the Tukey test at 5\% probability, four replications are sufficient to identify significant differences among the treatment means of $44.75 \%$ of the experiment mean.

\section{Conclusions}

There is variability of the plot size among cultivars and sowing dates in order to measure the fresh and dry matter in oat.

The optimum plot size of 6.62 and 6.93 basic experimental units ( 1.66 and $1.73 \mathrm{~m} 2$ ) are suitable to assess the fresh and dry matter of oat in the four cultivars and on the three sowing dates, respectively.

Four replications to evaluate the maximum of 50 treatments in completely randomized design and randomized blocks design are sufficient so that the differences among treatment means of $44.75 \%$ of the experiment mean may be significant, using the Tukey test at $5 \%$ probability to measure the fresh and dry matter in oat.

\section{Acknowledgements}

To the National Council of Technological and Scientific Development (CNPq), to the Coordination for the Improvement of Higher Education Personnel (CAPES) and to the Foundation for Research of the State of Rio Grande do Sul (FAPERGS), for granting scholarships to the authors. To the Ponteio Seeds Company, for donating the oat seeds that were used in this study. To the scholarship and volunteer students for their help in the data collection.

\section{References}

Burin, C., Cargnelutti Filho, A., Alves, B.M., Toebe, M., Kleinpaul, J.A., Neu, I.M.M. 2015. Plot size and number of repetitions in evaluation times in millet crop. Bragantia 74: 261-269.

Cardoso, R.A., Bento, A.S., Moreski, H.M., Gasparotto, F. 2014. Influence of green manure in physical and biological properties of soil and productivity in the culture of soybean. Semina: Ciências Biológicas e da Saúde 35: 51-60.

Cargnelutti Filho, A., Alves, B.M., Toebe, M., Burin, C., Santos, G.O., Facco, G., Neu, I.M. M., Stefanello, R.B. 2014a. Plot size and number of repetitions in black oat. Ciência Rural 44: 17321739. 
Cargnelutti Filho, A., Toebe, M., Burin, C., Casarotto, G., Alves, B.M. 2014b. Experimental designs in turnip sown to haul and in line. Bioscience Journal 30: 677-686.

Demétrio, J.V., Costa, A.C.T., Oliveira, P.S.R. 2012. Biomass yield of oat cultivars under different cutting management systems. Pesquisa Agropecuária Tropical 42: 198-205.

Ferrazza, J.M., Soares, A.B., Martin, T.N., Assmann, A.L., Nicola, V. 2013. Production of annual winter forages at different sowing times. Revista Ciência Agronômica 44: 379-389.

Ferreira, D.F. 2014. Sisvar: A guide for its bootstrap procedures in multiple comparisons. Ciência e Agrotecnologia 38: 109-112.

Floss, E.L., Palhano, A.L., Soares Filho, C.V., Premazzi, L.M. 2007. Growth, productivity, characterization and chemical composition of white oat. Acta Scientiarum Animal Sciences 29: $1-7$.

Frazer, G.W., Magnussen, S., Mulder, M.A., Niemann, K.O. 2011. Simulated impact of sample plot size and co-registration error on the accuracy and uncertainty of LiDAR-derived estimates of forest stand biomass. Remote Sensing Environment 115: 636-649.

Grecco, F.C.A.R., Cunha Filho, L.F.C., Okano, W., Silva, L.C., Zundt, M., Vianna, L.C. 2011 . Yield and chemical composition of temperate grasses in ARAPONGAS-PR. Colloquium Agrariae 7: 17-23.

IBGE (Instituto Brasileiro de Geografia e Estatística). 2014. Levantamento sistemático da produção agrícola.

lqbal, A., lqbal, M.A., Nabeel, F., Khan, H.Z., Akbar, N., Abbas, R.N. 2014. Economic and sustainable forage oat (Avena sativa L.) production as influenced by different sowing techniques and sources of nitrogen. American Eurasian Journal Agricultural \& Environmental Sciences 14: 10351040.

Khan, A., Anjum, M.H., Rehman, M.K.U. Zaman, Q., Ullah, R. 2014. Comparative study on quantitative and qualitative characters of different oat (Avena sativa L.) genotypes under agro-climatic conditions of sargodha, pakistan. American Journal of Plant Sciences 5: 3097-3103.

Lombardi, F., Marchetti, M., Corona, P., Merlini, P., Chirici, G., Tognetti, R., Burrascano, S., Alivernini, A., Puletti, N. 2015. Quantifying the effect of sampling plot size on the estimation of structural indicators in old-growth forest stands. Forest Ecology Management 346: 89-97.

Meinerz, G.R., Olivo, C.J., Fontaneli, R.S., Agnolin, C.A., Horst, T., Bem, C.M. 2012. Productivity of double-purpose winter cereals in the Depressão Central region of Rio Grande do Sul state. Revista Brasileira de Zootecnia 41: 873-882.

Meinerz, G.R., Olivo, C.J., Viégas, J., Nörnberg, J.L., Agnolin, A., Scheibler, R.B., Fontaneli, R.S. 2011. Silage of winter cereals submitted to double purpose management. Revista Brasileira de Zootecnia 40: 2097-2104.

Paranaíba, P.F., Ferreira, D.F., Morais, A.R. 2009. Optimum experimental plot size: Proposition of estimation methods. Revista Brasileira de Biometria 27: 255-268.

Smiderle, E.C., Botelho, F.B.S., Guilherme, S.R., Arantes, S.A.C.M., Botelho, R.T.C., Arantes, K.R. 2014. Optimal size experimental plots for the selection of genotypes of bean. Comunicata Scientiae 5: 51-58.

Soares, A.B., Pin, E.A., Possenti, J.C. 2013. Nutritive value of five cool-season forage species under four sowing dates. Ciência Rural 43: 120-125.

Storck, L., Garcia, D.C., Lopes, S.J., Estefanel, V. 2016. Experimentação vegetal. UFSM, Santa Maria, Brasil. 200 p.

Tafernaberri Júnior, V., Dall'Agnol, M., Montardo, D.P., Pereira, E.A., Peres, E.R., Leão, M.L. 2012. Agronomic evaluation of white oats strains in two geographical regions of the state of Rio Grande do Sul. Revista Brasileira de Zootecnia 41: 41-51. 